\title{
ВПЛИВ РОЗВИТКУ ІНФОРМАЦІЙНИХ ТЕХНОЛОГІЙ НА ЖИТТЄВИЙ ЦИКЛ ЕЛЕКТРОННОГО РЕСУРСУ
}

๑ К. О. Кобильнік, К.т.н., доцент, НТУУ «КПІ», Київ, Україна

В работе рассмотрено влияние развития информационных технологий на этапы жизненного цикла электронных ресурсов. Определены этапы жизненного цикла электронного ресурса и признаки, когда инновации отрасли информационных технологий начинают негативно влиять на функционирование ресурса. С целью улучшения эксплуатационных характеристик и эффективности электронного ресурса разработан редизайн сайта. В работе были применены адаптивный программный модуль, позволивший указать таблицу стилей для экранов разной ширины и создать кросс-браузерный адаптивный дизайн.

The impact of information technology on the life cycle stages of electronic resources was established. Stages of the life cycle of electronic resources were identified. The innovative of information technology affect to the functioning of the resource.

Solutions of information technology development will have adversely affect if the site does not meet them. The reprography department site of Publishing and Printing Institute NTUU “KPI» were analyzed by on these grounds. The new specification for web site was developed. According to the new specification was developed the design for electronic resources.

В наш час швидкоплинна зміна інформаційних технологій (IT) впливає на всі аспекти діяльності суспільства. Запорука успіху сучасних навчальних закладів, це їх присутність в цифровому просторі та відповідність сучасному рівню розвитку IT. Ці складові, а також питання загальної організації вирішуються на різних етапах життєвого циклу системи. Саме розвиток IT галузі вплинув на електронні ресурси (ЕР) освітніх установ та сайти їх департаментів. Аналіз ЕР провідних університетів світу, серед яких сайти Оксфордського, Кембриджського, Гар- вардського, Єльського, Барселонського університетів, а також сайт Федерального швейцарського технологічного інституту Цюриха та Київського політехнічного інституту, виявив тенденції в оновленні ЕР відповідно до сучасних вимог та деякі закономірності в макетуванні, виборі шрифтових рішень та кольорових гам, а також допоміг визначити мету роботи.

Отже, мета роботи полягає в наступному: по-перше, слід визначити етапи життєвого циклу ЕР та ознаки, коли інновації IT галузі починають негативно впливати на функціонування ре- 


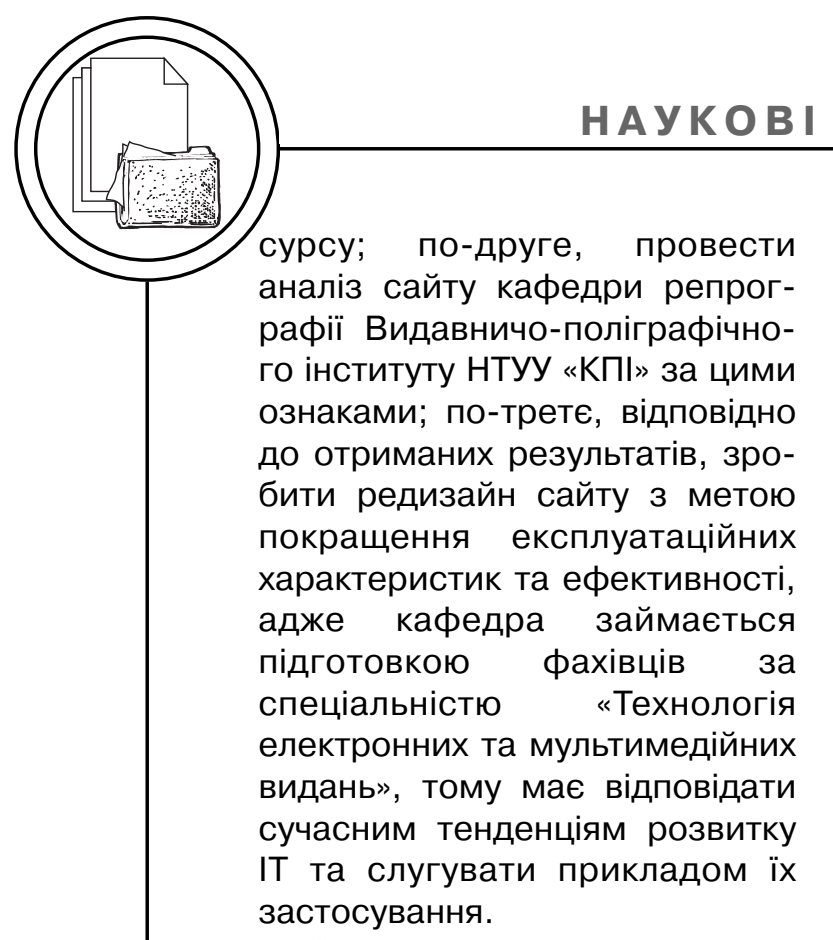

Слід зазначити, що під терміном «редизайн» розуміється як заміна зовнішнього вигляду (графіки та архітектоніки) ЕР, так і функціональної частини та системи управління. Ця заміна може бути повною або частковою. Фактично, редизайн ототожнюють 3 модернізацією, але коло функцій редизайну ширше.

Життєвий цикл ЕР освітньої сфери базується на IT, пов'язаний 3 їх розвитком та складається 3 наступних стадій: дослідження та обґрунтування розробки; проектування; виготовлення; експлуатація; утилізація. Розглянемо детально кожен етап життєвого циклу EP.

Етап дослідження та обґрунтування розробки

Обґрунтуванням слугує те, що презентація установи в мережі Інтернет має вирішувати низку задач. По-перше, - це комунікація з потенційною аудиторією, а комунікація, як відомо, має бути доступна, ненав'язлива, привітна та залишати бажан- ня повернутись до «спілкування». По-друге, сайт - це складова ділової репутації установи, тому дизайн має бути осмисленим та відповідати призначенню установи. Для створення ресурсу вихідних даних майже завжди достатньо. Дослідження стосується інноваційних розробок в галузі IT, що допомагає визначити перелік сервісів, які має надавати сайт та технологій, на яких буде базуватись проектування сайту.

\section{Етап проектування}

Проектування розпочинається з чіткого усвідомлення поставленої задачі, мети та вимог до ЕР. Постановка задачі викладається в технічних вимогах до даної системи. Вимоги визнаються 3 урахуванням особливостей установи та можливостями реалізації ідеї проекту відповідно до існуючого рівня IT.

\section{Етап виготовлення}

Цей етап полягає в комплектації системи з готових рішень; макетуванні; настройці системи; налаштуванні доступу до файлів, які знаходяться у файлових архівах; інсталяції системи управління сайтом та допоміжних програм; тестуванні системи та її публікації в мережі Інтернет.

\section{Етап експлуатації}

Стадія експлуатації, це період використання ЕР за призначенням. Для підтримки належного рівня якості ця стадія передбачає технічне обслуговування, модернізацію, редизайн та динамічне оновлення ресурсу. Розвиток IT та техніки тут має найсильніший вплив. На цьому етапі замовник та розробник 
відслідковують розвиток IT та техніки, враховують зауваження та побажання користувачів щодо експлуатаційних характеристик ресурсу. Отримані відомості використовують для покращення характеристик системи.

\section{Етап утилізації}

Ця стадія, передбачає вилучення ресурсу з мережі Інтернет.

В ході роботи визначено ознаки, наявність яких сигналізує про необхідність редизайну реcypcy.

1. Відповідність існуючому рівню розвитку технологій та техніки.

Сучасний сайт має відповідати існуючому рівню розвитку технологій та техніки, а також підтримувати сервіси, які вони пропонують. Поширення різноманітних мобільних пристроїв (планшетів, смартфонів та ін.) мають величезний вплив на трансформацію цифрових ресурсів та сприяють розробці програмних модулів та додатків для комфортного перегляду ЕР через мобільні пристрої. Тобто сучасний ЕР має бути адаптованим до новітніх форматів представлення інформації в мобільних пристроях. Адаптація має стосуватися як програмної частини так і дизайну.

Навчальні заклади щороку стикаються з конкурентною боротьбою за абітурієнтів. А це, як відомо, цільова аудиторія молодих, активних, спраглих до знань та всього нового людей. Виходить, що користувачи новітніх електронних пристроїв це і є потенційні абітурієнти. Отже, ресурс освітньої установи не в змозі ігнорувати ці зміни, якщо бажає бути конкурентоспроможним на ринку освітніх послуг.

2. Затримка часу завантаження сторінки.

Проблема виникає через неправильне опрацювання ілюстраційного матеріалу, тобто чим більший розмір файлів ЕР тим повільніше завантажується ресурс. Гальмування завантаження призводить до втрати користувачів. Ще один аспект, який необхідно враховувати, це об'єм використаного при завантаженні інтернет-трафіку, що $€$ суттєвим показником для користувачів мобільних пристроїв. Це також призводить до втрати потенційних користувачів.

3. Сайт перевантажено.

Це стосується вербальної інформації, тобто контенту ЕР. Якщо має місце завеликий обсяг тексту рубрик та (або) наявність надмірної кількості пунктів меню, то користувачеві важко знайти змістовну частину. Відчуття недоліків в контенті призводить до втрати потенційних користувачів. Засобами дизайну та влучним наповненням контенту слід досягти позитивного враження від стартової сторінки ЕР, тим самим забезпечивши інтерес до перегляду та ознайомлення 3 іншими вкладками.

4. Незручна навігація.

Зручність користування ЕР одна $з$ найважливіших характеристик. Частково, це питання звички відвідувачів інтернету знаходити інформацію там, де ї̈ розміщує переважна більшість сайтів. Якщо структура сайту не відображає логічну послідовність дій користувача, 
чи дизайн маскує головні елементи, чи акцентів забагато, то користувач залишає ресурс, не бажаючи витрачати час на дослідження, та починає шукати зрозумілий та простий в користуванні ресурс.

5. Змінились задачі ресурсу.

Задачі змінюються залежно від розвитку IT. Коло функцій системи розширюється, що дає привід для оновлення ресурсу.

6. Дизайн застарів.

Нові тренди, технології, програмні можливості для реалізації ідей дизайнера впливають на процес модернізації системи, та надають змогу виокремитись поміж різноманіття цифрового простору, зробити проект сучасним. Також відбувається моральне старіння, тому рекомендовано оновлювати ЕР кожні 3-5 років.

7. Застаріла інформація та непрацюючі посиланя.

Даний пункт вказує на відсутність динамічного оновлення сайту, а також на рейтинг відвідуваності даного ресурсу. Це безперечно негативно впливає на ділову репутацію установи та вимагає термінового виправлення помилок та своєчасного оновлення інформації.

8. Незадовільна система управління сайтом.

Система управління сайтом призначена забезпечити комфортну роботу з функціональною складовою ресурса. Функціональні можливості такої системи надають змогу управляти структурою ресурсу та його інформаційним наповненням, а також підтримувати роботу 3 рекламними блоками, встановлювати зв'язок з сторінками те- матичних груп соціальних мереж, блогами, форумами та ін. Тому, якщо така система незручна в користуванні або її коло функцій не задовільняє потреби EP, це спричиняє перепони в роботі з ресурсом, та відображається на його зовнішньому вигляді.

9. Сайт важко знайти в пошуковій системі.

Цей пункт 3'явився як наочний приклад впливу розвитку IT на життєвий цикл ЕР. Ще два роки тому, сайти «розкручували» В пошукових системах відповідно до певних правил. Зараз це питання пошукової оптимізації, яка має власний алгоритм роботи. Через ці зміни виникли проблеми з відображенням посилань на ЕР в пошукових системах. Просування ресурсу за всіма правилами пошукової оптимізації вимагає ґрунтовних знань в цій галузі та постійної роботи з семантичним ядром EP підчас всього циклу етапу експлуатації життєвого циклу ресурсу.

10. Нецікаві банери.

Тут діють закони реклами. Через співвідношення кольорів, шрифтове оформлення та змістовність зображення фахівці з реклами та PR вже давно навчились впливати на аудиторію, створювати відповідний настрій. Банери ЕР освітньої установи призначені демонструвати позитивні аспекти життя, пов'язані з навчанням.

Сайт кафедри репрографії розміщено за електронною адресою http://repro.vpi.kpi.ua. Макет існуючого сайту кафедри репрографії наведено на рис. 1. 


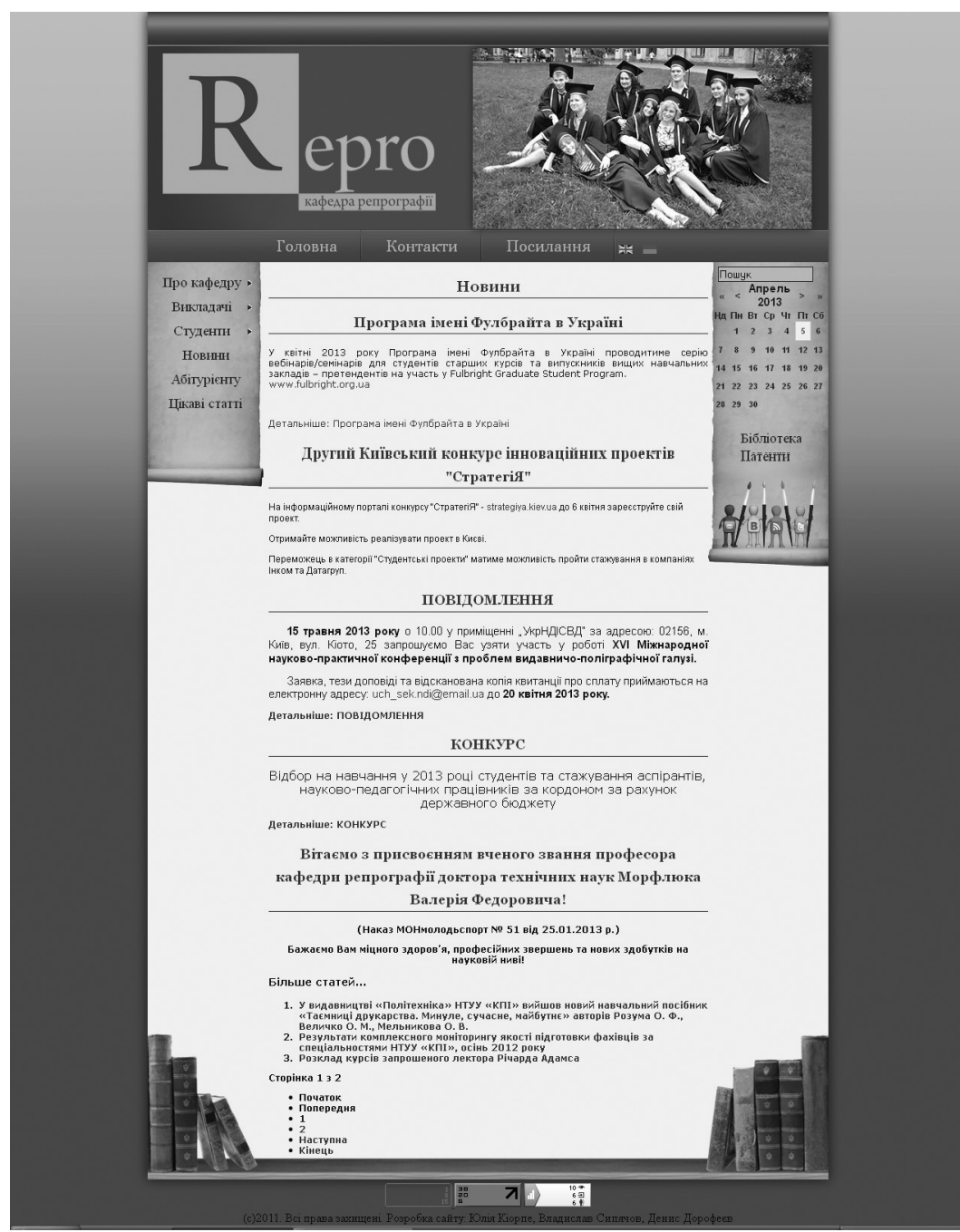

Рис. 1. Сайт кафедри репрографії

Аналіз сайту кафедри репрографії, відповідно до переліку вищезазначених ознак, виявив низку колізій. Розробка нового технічного завдання, надала змогу виправити вказані зауваження засобами редизайну ЕР.

1. Відповідність існуючому рівню розвитку технологій та техніки.

Сайт нормально працює при завантажені через стаціонарний комп'ютер, але користувачі більше не переглядають сайти лише на цих пристроях. Відвідувачі ресурсів використовують для доступу в інтернет мобільні телефони, невеликі ноутбуки, планшетні пристрої, такі як iPad або Playbook. При завантаженні через ці пристрої формат сайту кафедри не адаптувався. Виявилось, що традиційний дизайн з фіксованою шириною більше не задовольняє вимогам до функціональної складової ЕР. 


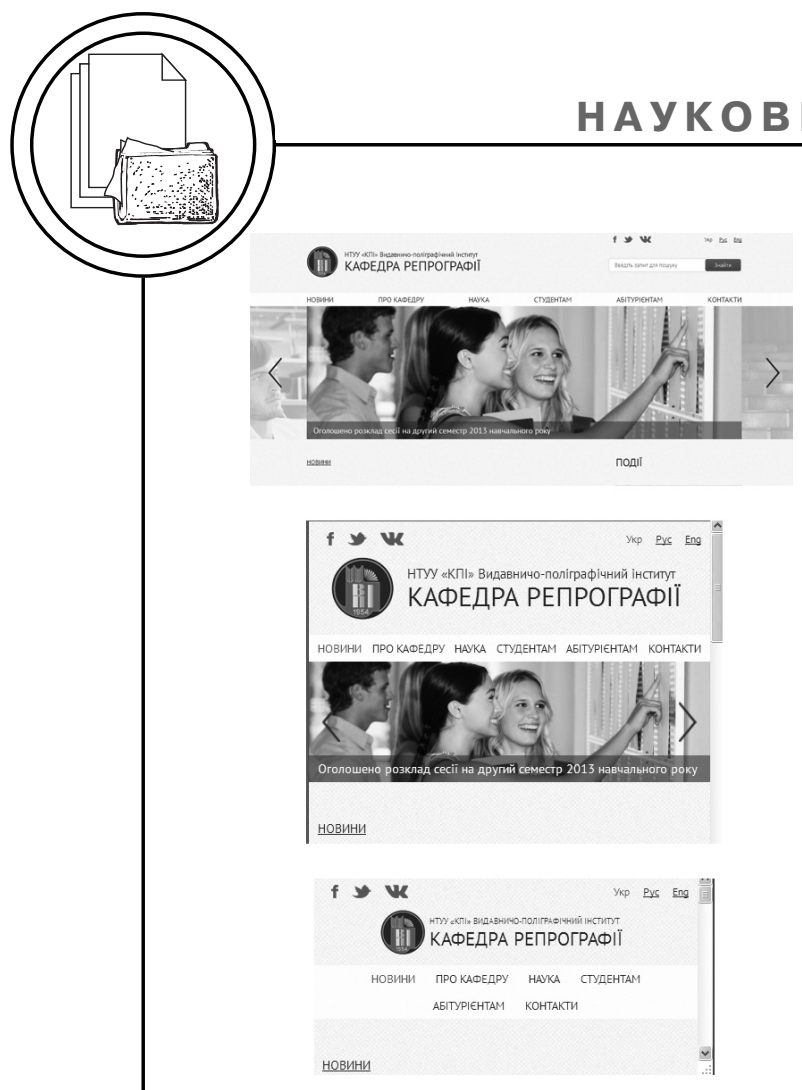

Рис. 2. Крос-браузерний адаптивний дизайн

Дизайн повинен бути адаптивним. Структура повинна автоматично змінюватися 3 урахуванням всіх дозволів дисплеїв, значення яких коливаються від 320px (iPhone) до 2560px (великі монітори) або навіть вище. 3 метою вирішення колізії, було застосовано адаптивний програмний модуль з CSS3 Media Queries, що дозволив вказати таблицю стилів для екранів різної ширини та створити кросбраузерний адаптивний дизайн. Media Queries перевіряє ширину макету i, якщо ширина менше ніж 980 рx, то макет масштабується, а якщо ширина менше ніж 650px, то банер приховується, а горизонтальна панель навігації розміщується в двох рівнях, якщо ж навігація бічна, то панель меню розширюється на всю ширину екрану.
Можливості крос-браузерного адаптивного дизайну оновленого сайту кафедри наведені на рис. 2.

2. Затримка часу завантаження сторінки.

Сайт повільно завантажується. 3 метою уникнення цього недоліку всі ілюстраційні файли пройшли додаткове опрацювання в Adobe Photoshop та були збережені у спеціальному форматі, що значно зменшив ї обсяг.

3. Сайт перевантажено.

Призначення сайту кафедри в забезпеченні користувачів інформацію про свою роботу, спеціальності, викладачів та ін. Це чималий обсяг даних, який призводить до перевантаження ресурсу. Щоб цього уникнути було змінено макетування ЕР, що розвантажило візуальне сприйняття ресурсу, але не зменшило його зміст. Було змінено гарнітуру та кегль основного тексту. Використання рублених шрифтів, тобто таких, які не мають засічок, візуально розвантажило ресурс.

Розділ «Новини», при динамічному наповненні, приховував актуальну інформацію в додатках. Зміна стилю подання новин, виправила цю проблему. Розміщення частини інформації в тематичних групах соціальних мереж надало змогу розвантажити сайт та прибрати розділ «Форум».

4. Незручна навігація.

Навігаційні панелі сайту розташовувались з усіх сторін, що призводило до плутанини та ускладнювало пошук інформації. Також, мало місце дублювання інформації розділів в підроз- 
ділах. 3 метою усунення вказаних недоліків було змінено та спрощено систему навігації сайту та допрацьовано рубрикацію.

5. Змінились задачі ресурсу.

Відповідно до стрімкого поширення мобільних пристроїв та розширення кола функцій, які вони надавали, змінились і задачі ресурсу. 3 метою більш зручного сприйняття інформації через планшети та смартфони було запропоновано використовувати інформаційну графіку або інфографіку, призначення якої в комплексному відображенні інформації. Застосування інфографіки надає змогу швидко зрозуміти змістовну частину статті або рубрики та спрощує пошук інформації на сайті.

6. Дизайн застарів.

Для аналізу кольорових та шрифтових рішень було використано ColorSchemer, Color Text Legibility, Kuler, Typetester [1-3]. Завдяки інтуїтивному та зрозумілому інтерфейсу значно спрощується процес підбору кольорової гами ЕР, а автоматично сформовані висновки щодо гармонійного співвідношення кольорів фону і тексту, надали змогу швидко провести аналіз ЕР. Базовий елемент дизайну сайту кафедри це сувій. Фон відображає колір папірусу, який має темний відтінок. До контенту застосовано звичайний шрифт с засічками, що ускладнює перегляд інформації через мобільні пристрої. Пам'ятаючи про те, що дизайн будьякого ЕР набуває морально застарілого вигляду через 3-5 років, було вирішено змінити кольорову гаму ресурсу, розміщення інформаційних блоків та панелі навігації.

7. Застаріла інформація та непрацюючі посилання.

На кафедрі частково змінився професорсько-викладацький склад, вийшли нові видання, були отримані патенти та ін. Як наслідок, інформація виявилась застарілою. Для вирішення цього недоліку були замінені всі непрацюючі посилання, також була оновлена інформація.

8. Незадовільна система управління сайтом.

Систему управління сайтом через низку причин, пов'язаних з функціональними можливостями системи та зручністю користування, було вирішено замінити.

9. Сайт важко знайти в пошуковій системі.

Сайт кафедри відображався в пошуковій системі Yandex, але не відображався в пошуковій системі Google. Для вирішення колізії, заново було проіндексовано карту сайту. Також були замінені назви файлів, що покращило показники пошукової оптимізації.

10. Нецікаві банери.

Банер на сайті ділив простір з великим за розміром логотипом кафедри. Було вирішено збільшити площу, яку займає банер, а логотип та назву кафедри розмістити над банером, зменшивши їх розмір. Призначення банера відображати сучасні події в житті кафедри, тому тематика фотографій була розширена, а деякі файли замінені на нові.

Вказані зауваження та вимоги можливо було задовольнити зробивши редизайн сайту. Но- 
вий дизайн сайту ${ }^{1}$ розроблено 3 урахуванням оновленого технічного завдання. Дизайн задовольняє вимогам, які висуваються до сучасних ЕР (рис. 3).

\section{Висновки}

В ході роботи було визначено етапи життєвого циклу ЕР та ознаки, коли розвиток IT починає негативно впливати на функціонування ресурсу.

Наявність цих ознак сигналізує про необхідність редизайну ресурсу. Також, було проведено аналіз сайту кафедри репрографії Видавничо-поліграфічного інституту НТУУ «КП।» за цими ознаками. Аналіз виявив низку недоліків та колізій в роботі ЕР. Відповідно до отриманих результатів, було розроблено технічне завдання для редизайну сайту з метою покращення експлуатаційних характеристик та ефективності системи. Вдалий редизайн вирішив низку проблем, які негативно впливали на роботу ресурсу. Дана робота наочно демонструє вплив розвитку IT галузі на етапи життевого циклу ЕР.

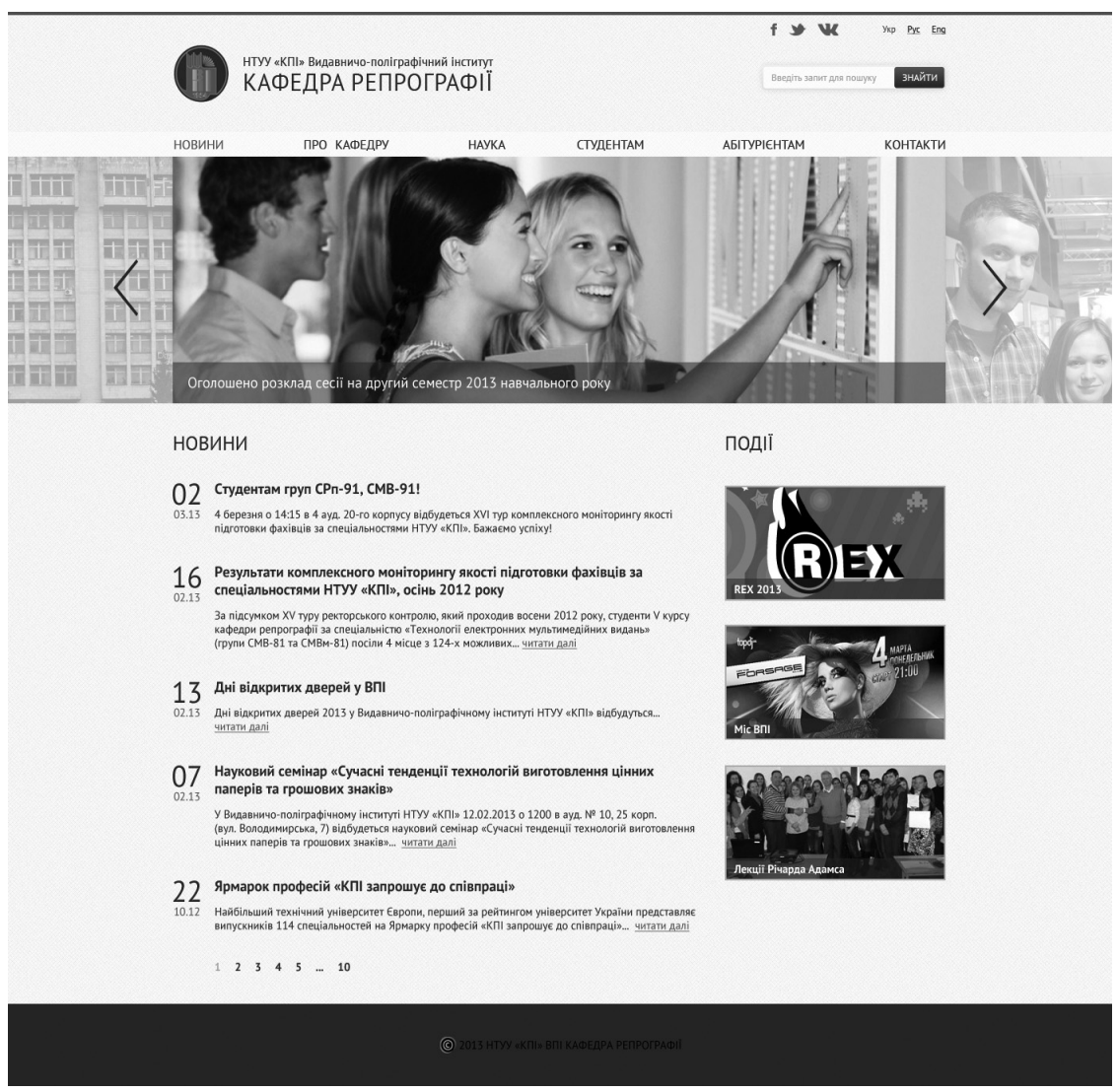

Рис. 3. Оновлений дизайн сайту кафедри репрографії

1Розробник дизайну: студент групи СРп-91 Д. Барило. 
1. Вибір шрифта [Електронний ресурс] : 2013 - Назва з екрана. URI (Унифицированный идентификатор ресурса): http://www.typetester.org. 2. Вибір кольорової палітри ColorShemer [Електронний ресурс] : $2013-\mathrm{Ha}-$ зва 3 екрана. URI (Унифицированный идентификатор ресурса) : https://kuler.adobe.com. 3. Перевірка читабельності кольоро-шрифтового поєднання [Електронний ресурс] : 2013 - Назва з екрана. URI (Унифицированный идентификатор ресурса) : http://www.hgrebdes.com/colour/spectrum/colourvisibility.html.

1. Vybir shryfta [Elektronnyi resurs] : 2013 - Nazva z ekrana. URI (Unificirovannyj identifikator resursa): http://www.typetester.org. 2. Vybir kolorovoi palitry ColorShemer [Elektronnyi resurs] : 2013 - Nazva z ekrana. URI (Unificirovannyj identifikator resursa) : https://kuler.adobe.com. 3. Perevirka chytabelnosti koloro-shryftovoho poiednannia [Elektronnyi resurs] : 2013 Nazva z ekrana. URI (Unificirovannyj identifikator resursa) : http://www.hgrebdes.com/colour/spectrum/colourvisibility.html.

Рецензент - О. М. Величко, д.т.н., професор, НТУУ «КПI»

Надійшла до редакції 27.03.13 